\title{
Effects of Whole Corn Germ, a Source of Linoleic Acid, on Carcass Characteristics and Meat Quality of Feedlot Lambs
}

\author{
Camila O. Nascimento ${ }^{1, *}$, Douglas S. Pina ${ }^{1}$, Luís G. A. Cirne ${ }^{2}$, Stefanie A. Santos ${ }^{1}$, Maria L. G. M. L. Araújo ${ }^{1}$, \\ Thomaz C. G. C. Rodrigues ${ }^{1}$, William P. Silva ${ }^{1}$, Mateus N. S. Souza ${ }^{1}{ }^{(D}$, Henry D. R. Alba ${ }^{1}$ \\ and Gleidson G. P. de Carvalho ${ }^{1, *(\mathbb{D})}$
}

Citation: Nascimento, C.O.; Pina, D.S.; Cirne, L.G.A.; Santos, S.A.; Araújo, M.L.G.M.L.; Rodrigues, T.C.G.C.; Silva, W.P.; Souza, M.N.S.; Alba, H.D.R.; de Carvalho, G.G.P. Effects of Whole Corn Germ, a Source of Linoleic Acid, on Carcass Characteristics and Meat Quality of Feedlot Lambs. Animals 2021, 11, 267. https://doi.org/10.3390/ani11020267

Academic Editor: Virginia Alice Cruz dos Santos, Severiano R. Silva and Cristina Miranda Guedes Received: 18 December 2020 Accepted: 19 January 2021 Published: 21 January 2021

Publisher's Note: MDPI stays neutral with regard to jurisdictional claims in published maps and institutional affiliations.

Copyright: (c) 2021 by the authors. Licensee MDPI, Basel, Switzerland. This article is an open access article distributed under the terms and conditions of the Creative Commons Attribution (CC BY) license (https:/ / creativecommons.org/licenses/by/ $4.0 /)$.
1 Department of Animal Science, Federal University of Bahia, Avenue Adhemar de Barros, 500, Ondina, Salvador 40170110, Brazil; douglaspinaufba@gmail.com (D.S.P.); stefanie_zootecnia@hotmail.com (S.A.S.); mariaaleonor@hotmail.com (M.L.G.M.L.A.); thomazguimaraes@yahoo.com.br (T.C.G.C.R.); willianzoo@yahoo.com.br (W.P.S.); mateusnetosilva@hotmail.com (M.N.S.S.); harrydoo@gmail.com (H.D.R.A.)

2 Institute of Biodiversity and Forestry, Federal University of Western, Vera Paz Street, Salé, Santarém 68040255, Brazil; lgabrielcirne@hotmail.com

* Correspondence: milaoliver.vet@gmail.com (C.O.N.); gleidsongiordano@ufba.br (G.G.P.d.C.); Tel.: +55-669233-8332 (C.O.N.); +55-713283-6719 (G.G.P.d.C.)

Simple Summary: The industrialization of corn generates several by-products, including the whole corn germ (WCG). This, in turn, shows promise in diets for ruminants because it contains $85 \%$ of the total lipids that can increase the diets' energy density (lipids naturally protected by the pericarp). Furthermore, WCG has around 56\% linoleic acid (of total fatty acids), contributing to increased unsaturated fatty acid concentrations in meat. This research aims to evaluate the quantitative carcass traits and the quality of lambs' meat supplemented with WCG to determine its optimum inclusion level in feedlot animals' diet.

Abstract: The whole corn germ (WCG), due to its desirable nutritional characteristics, has been studied as feed for ruminants. This study aimed to evaluate the effects of WCG inclusion as a linoleic acid source in diets for feedlot lambs on carcass characteristics, physicochemical composition, sensory attributes, and fatty acid profile of the meat. Forty non-castrated, crossbreed Dorper $x$ Santa Inês lambs were distributed in a completely randomized design to evaluate the inclusion levels $(0,30,60$, 90 , and $120 \mathrm{~g} / \mathrm{kg}$ dry matter (DM)) of whole corn germ (WCG) in the diet. The dietary inclusion of WCG did not influence $(p>0.05)$ the weight gain and carcass characteristics, with the exception of the subcutaneous fat thickness $(p<0.01)$, which was higher in animals fed diets with higher levels of WCG. Lightness ( $\left.\mathrm{L}^{*} ; p=0.04\right)$, yellowness $\left(\mathrm{b}^{*} ; p<0.01\right)$, shear force $(p=0.04)$, linoleic fatty acid concentrations $(p=0.03)$, and total polyunsaturated fatty acids $(p=0.04)$ had a quadratic increase due to WCG inclusion in the diets. The use of up to $120 \mathrm{~g} / \mathrm{kg}$ DM of WCG in lamb diets does not affect the carcass characteristics, physicochemical composition, and sensory attributes of the meat. Despite this, the best polyunsaturated fatty acid profile in lambs' meat is obtained using $76.7 \mathrm{~g} / \mathrm{kg}$ DM of WCG.

Keywords: by-product; fatty acids; meat; nutrition; sheep

\section{Introduction}

Corn is one of the most used cereals in the world. Its industrialization process in the bioethanol production generates several by-products, among them distillers dried grains, whole corn germ (WCG), the outer seed shell, and oil [1-3]. These by-products can be used in animal and human feeding, biofuel and feedstock production, or other systems. The WCG is obtained from the wet degermination of corn grain by a mechanical extraction process [4]. 
The WCG has been studied in diets for ruminants due to its crude protein (10 to $15 \%$ ) [5,6], ether extract (44\%) [1], and linoleic acid (56\% of total fatty acids) contents [1]. The inclusion of WCG in the ruminant diets aims to increase energy density [7] and polyunsaturated fatty acids, to obtain higher levels of conjugated linoleic acid (CLA) in the meat, which are beneficial to human health [8].

Given the importance of incorporating nutraceutical components in red meat, studies have been conducted to decrease the saturated fatty acid (SFA):polyunsaturated fatty acid (PUFA) ratio, maintaining the balance of the omega 6:omega 3 ratio [8]. Furthermore, it is aimed to increase the concentrations of CLA in the meat of ruminants [9]. The CLAs are biohydrogenation intermediates that, from the hydrogenation of linoleic acid by ruminal microorganisms, can pass from the rumen to be absorbed by the intestine. Subsequently, they are then incorporated into the meat of ruminants [10].

The WCG contains $85 \%$ of the total lipids in the grain [11], which is naturally protected by the pericarp. Therefore, this protection could decrease the biohydrogenation activity of ruminal bacteria on the unsaturated lipids present in the germ. Moreover, it increases the level of unsaturated lipids that will reach the intestine and, consequently, is incorporated into the meat [9].

To our knowledge, there are few studies with contradictory results of the dietary inclusion of WCG as a source of linoleic acid in diets for lambs. Given the nutritional characteristics, it is hypothesized that there is an inclusion level of WCG that increases diets' energy density for feedlot lambs, improving performance, carcass yield, and quality due to the increase of the unsaturated fatty acid deposition in the meat.

This study aimed to evaluate the effects of whole corn germ inclusion as a linoleic acid source in diets for feedlot lambs on the carcass characteristics, physicochemical composition, sensory attributes, and fatty acid profile of the meat.

\section{Materials and Methods}

\subsection{Location and Ethical Considerations}

The experiment took place at the Experimental Farm of the Federal University of Bahia, located in the municipality of São Gonçalo dos Campos, Bahia, Brazil. This study was conducted in strict accordance with the recommendations presented in the Guide of the National Council for Animal Experimentation Control (CONCEA). The protocol was approved by the Ethics Committee on the Animal Use of the School of Veterinary Medicine and Animal Science at the Federal University of Bahia (Permit number: 70/2018).

\subsection{Animals, Experimental Design, General Procedures, and Diets}

Forty non-castrated, crossbreed Dorper $\times$ Santa Inês lambs with an average age of 4 months and an average initial body weight (BW) of $22.1 \pm 4.0 \mathrm{~kg}$ (mean \pm standard deviation) were distributed in a completely randomized design with five treatments and eight replicates (animals).

Lambs were housed in individual, covered stalls with suspended slatted wooden floors measuring $1.2 \mathrm{~m}^{2}(1.2 \times 1.0 \mathrm{~m})$, equipped with drinkers and feeding throughs. They received water ad libitum, and the experimental diets twice daily. Before the experiment began, all animals were identified and vaccinated (rabies and clostridial vaccines). They were then allocated at random to the treatments.

The lambs were kept in the feedlot for 75 days, which were preceded by a 15-day period of acclimation to the facilities, daily management, and diets. During this phase, they received diets composed of $500 \mathrm{~g} / \mathrm{kg}$ of sorghum silage (Sorghum bicolor (L.) Moench) and $500 \mathrm{~g} / \mathrm{kg}$ of concentrate mixture comprised of soybean meal, ground corn, WCG, urea, and a commercial mineral premix (Table 1). 
Table 1. Proportion of ingredients, chemical composition, and fatty acid profile of the experimental diets and whole corn germ (WCG).

\begin{tabular}{|c|c|c|c|c|c|c|}
\hline \multirow{2}{*}{ Item } & \multicolumn{5}{|c|}{ Whole Corn Germ (g/kg DM) } & \multirow{2}{*}{ WCG } \\
\hline & $\mathbf{0}$ & 30 & 60 & 90 & 120 & \\
\hline \multicolumn{7}{|c|}{ Ingredient proportion (g/kg DM) } \\
\hline Sorghum silage & 500 & 500 & 500 & 500 & 500 & - \\
\hline Ground corn & 330 & 303 & 276 & 248 & 221 & - \\
\hline Soybean meal & 145 & 142 & 139 & 137 & 134 & - \\
\hline Whole corn germ & 0 & 30 & 60 & 90 & 120 & - \\
\hline Urea & 10 & 10 & 10 & 10 & 10 & - \\
\hline Mineral supplement ${ }^{1}$ & 15 & 15 & 15 & 15 & 15 & - \\
\hline & \multicolumn{6}{|c|}{ Chemical composition (g/kg as-fed) } \\
\hline \multirow[t]{2}{*}{ Dry matter (DM) } & 594 & 595 & 596 & 596 & 597 & 920 \\
\hline & \multicolumn{6}{|c|}{ Chemical composition (g/kg DM) } \\
\hline Organic matter & 843 & 844 & 845 & 846 & 847 & 911 \\
\hline Mineral matter & 37 & 37 & 37 & 37 & 36 & 93 \\
\hline Crude protein & 175 & 175 & 174 & 174 & 174 & 137 \\
\hline Ether extract & 31 & 42 & 54 & 65 & 76 & 414 \\
\hline Neutral detergent fiber & 394 & 402 & 409 & 416 & 423 & 418 \\
\hline Acid detergent fiber & 198 & 203 & 208 & 213 & 218 & 208 \\
\hline NIDP $^{2}$ & 7.6 & 7.4 & 7.3 & 7.2 & 7.0 & 11 \\
\hline $\mathrm{ADIP}^{3}$ & 3.8 & 3.7 & 3.7 & 3.7 & 3.6 & 3.0 \\
\hline Cellulose & 96 & 100 & 104 & 108 & 112 & 159 \\
\hline Hemicellulose & 196 & 198 & 200 & 202 & 204 & 210 \\
\hline Lignin & 102 & 103 & 104 & 105 & 106 & 48 \\
\hline \multirow[t]{2}{*}{ Non-fibrous carbohydrates } & 360 & 343 & 325 & 307 & 289 & 21 \\
\hline & \multicolumn{6}{|c|}{ Fatty acid profile (mg/kg of diet) } \\
\hline Total & 21,877 & 33,484 & 45,091 & 56,688 & 68,295 & 434,910 \\
\hline Caprylic (C8:0) & 4.0 & 5.0 & 6.0 & 6.0 & 7.0 & 2.0 \\
\hline Capric (C10:0) & 36 & 41 & 47 & 52 & 57 & 247 \\
\hline Lauric (C12:0) & 50 & 55 & 60 & 66 & 71 & 287 \\
\hline Myristic (C14:0) & 419 & 575 & 730 & 885 & 1041 & 6035 \\
\hline Palmitic (C16:0) & 3392 & 4924 & 6457 & 7989 & 9522 & 58,344 \\
\hline Palmitoleic (C16:1) & 81 & 103 & 125 & 146 & 168 & 875 \\
\hline Stearic (C18:0) & 724 & 1016 & 1309 & 1601 & 1894 & 11,181 \\
\hline Oleic (C18:1 n-9) & 5848 & 9937 & 14,026 & 18,108 & 22,197 & 150,108 \\
\hline Linoleic (C18:2 n-6) & 9974 & 15,079 & 20,183 & 25,283 & 30,387 & 192,030 \\
\hline$\alpha$-linolenic (C18:3n-3) & 517 & 599 & 680 & 763 & 844 & 3485 \\
\hline
\end{tabular}

${ }^{1}$ Assurance levels (provided per kilogram of active elements): zinc $-3.800 \mathrm{mg}$, sodium-147.00 g, manganese-2.000 mg, cobalt-15.00 mg, copper $-590.00 \mathrm{mg}$, sulfur $-20.00 \mathrm{~g}$, iodine $-50.00 \mathrm{mg}$, chromium $-20.00 \mathrm{mg}$, molybdenum $-300.00 \mathrm{mg}$, calcium (min)—110.00 g, calcium $(\max )-135.00 \mathrm{~g}$, and fluorine $(\max )-87.00 \mathrm{mg} .{ }^{2}$ Neutral detergent insoluble protein. ${ }^{3}$ Acid detergent insoluble protein.

The experimental diets consisted of $0,30,60,90$, and $120 \mathrm{~g} / \mathrm{kg}$ WCG inclusion in diets (dry matter basis). The diets were formulated to supply the nutritional requirements of growing male lambs with a gain of $200 \mathrm{~g} /$ day as recommended by the National Research Council [12].

Animals were fed twice per day (09:00 $\mathrm{h}$ and 16:00 h), divided equally into two meals, as a total mixed ration (TMR). Nutrient intake was determined based on the difference between the amount of each nutrient contained in the feed offered and the feed refused during the experimental period. The amount of feed was adjusted daily, with an acceptable refusal amount about 10 to $20 \%$ of the total amount supplied to ensure ad libitum intake.

\subsection{Chemical Analysis of Ingredients and Diets}

During the feedlot period, samples of roughage, ingredients, diets, and refusals were weighed daily, harvested weekly, and subsequently frozen at $-20^{\circ} \mathrm{C}$. At the end 
of the experimental period, the samples were then thawed, pre-dried in a forced-air oven at $55{ }^{\circ} \mathrm{C}$ for $72 \mathrm{~h}$, and ground through a Wiley cutting mill with a 1-mm sieve. Ground samples were analyzed according to the methods of the Association of Official Analytical Chemistry [13] for dry matter (DM; method 934.01), ash (method 942.05), crude protein $(\mathrm{CP}=\mathrm{N} \times 6.25$; method 968.06), and ether extract (EE; method 920.39) contents. The organic matter $(\mathrm{OM})$ content of forage and feeds was determined by the following formula: OM $(\% \mathrm{DM})=100-$ ash $(\% \mathrm{DM})$.

The neutral detergent fiber was determined according to Mertens [14], using heatstable alpha-amylase without the addition of sodium sulfite to the detergent, and acid detergent fiber (ADF) as described by Van Soest et al. [15]. Ingredients were also evaluated for lignin (method 973.18; AOAC) [16], by solubilization of cellulose with $72 \%(w / v)$ sulphuric acid.

The neutral (NDIP) and acid detergent insoluble protein (ADIP) contents were determined according to the methods of Licitra et al. [17]. Non-fibrous carbohydrates (NFC) contents were estimated according to Hall [18] and expressed in percentage.

\subsection{Slaughtering Procedures and Carcass Characteristics}

At the end of the experiment, animals were transported to a commercial slaughterhouse, subjected to a 16-h fasting period, and weighed to determine the final weight (FW). They were then stunned using the proper equipment to promote electronarcosis. Then, the animals were suspended, bled from the jugular vein and carotid artery before being skinned, and eviscerated according to the recommendations of procedures for handling and humane slaughter of the animals [19].

The mean $\mathrm{pH}$ was obtained by analyzing (in triplicate) the Longissimus lumborum (LL) muscles $45 \mathrm{~min}$ (initial) and $24 \mathrm{~h}$ after slaughter (final), using a digital HANNA skewer type HI 99163, connected to a penetration electrode, previously calibrated with pH 4.01 and 7.01 buffer solutions.

After the slaughter, carcasses were weighed to determine the hot carcass weight $(\mathrm{HCW})$ and the hot carcass yield $(\mathrm{HCY}=\mathrm{HCW} \times 100 / \mathrm{FW})$ and then transferred to a cold chamber $\left(5^{\circ} \mathrm{C}\right)$, where they remained for $24 \mathrm{~h}$. Subsequently, the carcasses were weighed to determine the cold carcass weight $(\mathrm{CCW})$ and cold carcass yield $(\mathrm{CCY}=\mathrm{CCW} \times 100 / \mathrm{FW})$.

After the $24 \mathrm{~h}$ slaughtering period, the carcasses were subjectively evaluated for conformation, finishing, and fatness using a visual scale, from 0 to 5, as proposed by Cezar and Sousa [20], and the marbling of the meats. The carcass morphometric measurements were measured according to Osório et al. [21]. The measured parameters included the internal length, external length, leg length, leg circumference, rump width, chest width, chest depth, rump perimeter, and chest perimeter. The length and perimeter measures were taken using a tape measure, whereas those related to width and depth, with a manual meter aid.

The carcasses were cut longitudinally at the midline into two symmetrical antimeres. The carcass antimeres were sectioned between the 12th and 13th ribs to collect the loins (LL muscle) according to the methods described by Colomer-Rocher et al. [22]. Afterward, the loin eye area (LEA) was assessed using plastic transparency sheets and an appropriate pen. Thus, the following measures were established: the length and the maximum depth of the LL muscle, in $\mathrm{cm}$, measured with the aid of a ruler and calculated from the ellipse formula: LEA $=($ length $/ 2 \times$ depth $/ 2) \pi$, in $\mathrm{cm}^{2}$, proposed by Silva Sobrinho [23].

The subcutaneous fat thickness (SFT) in the carcasses was measured, in $\mathrm{mm}$, with the aid of a digital caliper at $\frac{3}{4}$ distance from the medial side of the LL muscle, to the side of the spinous process. Subsequently, loins from the left and right sides were collected from each animal and immediately weighed, deboned, identified, vacuum packed in polyethylene packs, and stored at $-20^{\circ} \mathrm{C}$ for further evaluation of physicochemical analysis, sensory attributes, and fatty acid profile. 


\subsection{Meat Physicochemical and Sensory Analysis}

Meat analysis was performed after thawing the loins in plastic bags $\left(10^{\circ} \mathrm{C}\right.$ for $\left.12 \mathrm{~h}\right)$. The samples were then dissected with the aid of a scalpel and knife. The color parameters were evaluated using the left side of the loins collected from the lambs. The color parameters were determined with the aid of a Minolta CR- 400 colorimeter, using the CIELAB (Commission Internationale de $\mathrm{l}^{\prime}$ Eclairage $\mathrm{L}, \mathrm{a}^{*}, \mathrm{~b}^{*}$ ) system through the coordinates of lightness $\left(\mathrm{L}^{*}\right)$, redness $\left(\mathrm{a}^{*}\right)$, and yellowness $\left(\mathrm{b}^{*}\right)$. The colorimeter was calibrated with a white ceramic plate and illuminant $C, 10^{\circ}$, for standard observation, and it was operated using an open cone.

Evaluation of meat color was carried out after the myoglobin was oxygenated by exposing the LL to the atmosphere for five minutes [24]. Then, as described by Miltenburg et al. [25], the $\mathrm{L}^{*}, \mathrm{a}^{*}$, and $\mathrm{b}^{*}$ coordinates were measured at three different points on the muscle surface, and subsequently averaged in triplicate for each coordinate per animal.

Cooking weight losses (CWL) of LL muscle were measured in each loin sample with $1.5 \mathrm{~cm}$ thickness, $3.0 \mathrm{~cm}$ length, and $2.5 \mathrm{~cm}$ width cubic samples (in triplicate), free of visible connective tissue. Raw samples were weighed, placed in an aluminum-coated tray, and cooked in a preheated oven at $170{ }^{\circ} \mathrm{C}$ until the center reached $70{ }^{\circ} \mathrm{C}$, measured using a copper-constantan thermocouple equipped with a digital reader. Subsequently, samples were cooled at room temperature and weighed again. The cooking weight loss of each sample was obtained as the difference between the weights before and after cooking [26].

The Warner-Bratzler shear force (WBSF) analyses were determined using the same cooked meat samples used to measure cooking losses. At least three cores $25 \mathrm{~mm}$ in diameter $\times 25 \mathrm{~mm}$ in length were removed from each sample. The WBSF was measured by a texture analyzer (Texture Analyzer TX-TX2; Mecmesin, Nevada, United States) fitted with a Warner-Bratzler-type shear blade according to the standard procedure described by Wheeler et al. [27]. The WBSF values were expressed in $\mathrm{kgf} / \mathrm{cm}^{2}$.

Evaluation of the proximate composition was carried out using the samples of LL muscles (in natura), which were lyophilized for $72 \mathrm{~h}$. They were then ground using a ball mill and analyzed for moisture, ash, protein, and total lipids contents according to the methods described by the AOAC [13].

The LL samples used in the sensory characteristics were evaluated using an unstructured hedonic scale of nine points by 100 untrained panelists. All panelists included 61 women and 31 men in an age group between 19 and 50 years of age accustomed to eating lamb meat. The samples were cooked on an electric grill (George Foreman Grill Jumbo GBZ6BW model) with the aid of a digital thermocouple. The thermocouple was inserted in the geometric center of each sample to monitor the temperature of each steak, which was cooked until the geometric center reached $75^{\circ} \mathrm{C}$. After cooking, the samples of LL muscle of lambs fed different WCG inclusion levels $(0,30,60,90$, and $120 \mathrm{~g} / \mathrm{kg})$ were then cut into cubes. Afterward, they were transferred to encoded pre-heated beakers, which were placed in a water bath $\left(75^{\circ} \mathrm{C}\right)$ and covered with aluminum foil to ensure minimum heat loss and aroma volatiles.

The tests were carried out between 09:00 and 12:00 h, and consumers were placed in individual cabins. During the sensory evaluation, each taster was provided two samples per treatment without salt or condiments in plastic containers with coded lids; each taster also received water and cream cracker-type biscuits for intake between tastings to remove the residual flavor.

The sensory attributes of the LL muscle were evaluated using an affective method on a structured hedonic scale. The tasters evaluated the following attributes: taste, tenderness, juiciness, aroma, and overall acceptance. The scores ranged from 1 to 9 , as follows: 1 , disliked very much; 2 , disliked; 3 , moderately disliked; 4 , slightly disliked; 5 , indifferent; 6 , slightly liked; 7 , moderately liked; 8 , liked; and 9, liked very much). The intensities of the lamb meat flavor and aroma characteristics were also evaluated according to American Meat Science Association (AMSA) [28]. 


\subsection{Fatty Acid Profile}

The composition of lipids extracted from the samples of diets and LL was determined by converting the lipid extracts to fatty acid methyl esters (FAMEs). Afterward, FAMEs were prepared following the methodology described by O'Fallon et al. [29].

Meat samples (in natura) were ground (homogenized) in grinder (Cadence $150 \mathrm{~W}$ MDR 302), lyophilized for five days, and milled (homogenized) again. Approximately $0.5 \mathrm{~g}$ of dry sample was placed in a $16 \times 125 \mathrm{~mm}$ pyrex culture tube, which contained $1.0 \mathrm{~mL}$ of internal standard C19:0 (189-19 Sigma Aldrich, São Paulo, Brazil; $10 \mathrm{mg}$ of C19:0/mL of $\mathrm{MeOH}$ ), added with $0.7 \mathrm{~mL}$ of $10 \mathrm{~N} \mathrm{KOH}$ in water, $5.3 \mathrm{~mL}$ of $\mathrm{MeOH}$. The tubes were incubated at $55{ }^{\circ} \mathrm{C}$ in a water bath for $1 \mathrm{~h} 30 \mathrm{~min}$ with vigorous stirring to permeate every $20 \mathrm{~min}$ to dissolve and hydrolyze the sample. After cooling in an ice-water bath, $0.58 \mathrm{~mL}$ of $24 \mathrm{~N} \mathrm{H}_{2} \mathrm{SO}_{4}$ in water was added. The contents of the tubes were mixed by shaking and precipitated with $\mathrm{K}_{2} \mathrm{SO}_{4}$. They were then incubated in a water bath at $55^{\circ} \mathrm{C}$ for $1 \mathrm{~h} 30 \mathrm{~min}$ with shaking for $5 \mathrm{~s}$ every $20 \mathrm{~min}$.

After synthesizing the FAMEs, the tubes were cooled in an ice-water bath. Subsequently, $3 \mathrm{~mL}$ of hexane was added, and the contents of the tubes were mixed for $5 \mathrm{~min}$ using a vortex. Subsequently, tubes were immediately centrifuged for $5 \mathrm{~min}$, and supernatant with hexane containing FAME was transferred to gas chromatography vials. The vials were capped and placed at $-20^{\circ} \mathrm{C}$ until analyses.

The FAME composition was determined using a gas chromatograph (SPTM-2560) column (100 m-25 mm-0.2 $\mu \mathrm{m}$ pore size) with a flame ionization detector and split injector (Thermo Scientific Inc.) and the hydrogen as the carrier gas $\left(1 \mathrm{~mL} \mathrm{~min}^{-1}\right)$. Nitrogen was used as the auxiliary gas. The temperature of the injector and detector was $250{ }^{\circ} \mathrm{C}$ at a 15:1 split. The initial temperature of the oven was adjusted to $70^{\circ} \mathrm{C}$; this temperature was maintained for $4 \mathrm{~min}$, and gradually increased (at $13^{\circ} \mathrm{C} /$ minute) until reaching $175^{\circ} \mathrm{C}$, where it remained for $27 \mathrm{~min}$. Then, it was increased (at $4{ }^{\circ} \mathrm{C} /$ minute) until reaching $215^{\circ} \mathrm{C}$, which was maintained for $31 \mathrm{~min}$ [30].

Identification of FAs was performed comparing the retention times of FAME to those of the standards (37 Component FAME Mix from Supelco Inc., Sigma Aldrich Darmstadt, Germany) and published chromatograms [31,32]. The quantification of FAMEs was conducted based on the equation proposed by Sukhija and Palmquist [33]: ((total area of the peaks - area of the internal standard)/area of the internal standard) $\times$ (concentration of the internal standard/weight of the lyophilized sample)). Fatty acid profile was expressed in milligrams of fatty acids per $\mathrm{kg}$ of meat $(\mathrm{mg} / \mathrm{kg})$.

The group sums, ratios, and total contents of the saturated fatty acids (SFAs), monounsaturated fatty acids (MUFAs), and polyunsaturated fatty acids (PUFAs), and the MUFA:SFA, PUFA:SFA, PUFA:MUFA, and $n-6 / n-3$ values were calculated from the identified FA profiles.

The desirable fatty acids (DFA) were calculated according to Rhee [34]. The activity indexes of the elongase and $\Delta^{9}$-desaturase enzymes for FAs with 16 and 18 carbons were determined using the methodology proposed by Malau-Aduli et al. [35] and Kazala et al. [36].

The nutritional quality of the lipid fraction of the LL muscle, the atherogenicity (AI), and thrombogenicity (TI) indexes were calculated as proposed by Ulbricht and Southgate [37]. The ratio of hypocholesterolemic:hypercholesterolemic $(\mathrm{h}: \mathrm{H})$ fatty acids ratio, as well as the concentrations of hypercholesterolemic, neutral, and hypocholesterolemic fatty acids, were evaluated and adapted according to Bessa [38] and Santos-Silva, Bessa, and Mendes [39].

\subsection{Statistical Analyses}

The experiment was conducted as a completely randomized design with five treatments and eight replicates (lambs) per treatment. The following statistical model was used:

$$
\hat{Y} i j=\mu+N L i+\varepsilon i j
$$


where $\hat{Y} i j=$ the observed value in the portion that received the treatment $i$ in repetition $j$; $\mu=$ the overall mean; $\mathrm{NLi}=$ the fixed effect of the inclusion level of whole corn germ $(i=0$, $30,60,90$, and $120 \mathrm{~g} / \mathrm{kg}$ ); and $\varepsilon \mathrm{ij}=$ the effect of experimental error associated with each presupposition observation normal independent distribution (NID) $\sim(0, \sigma 2)$.

The data were subjected to analysis of variance and regression testing, with the freedom degrees evaluated by linear or quadratic effects. The command PROC MIXED of SAS (version 9.4, SAS Institute Inc.) was used to estimate the linear or quadratic parameters of significant models. To quadratic models, the maximum or the minimum point were obtained by making the second derivative of the quadratic model equal to zero.

The data related to sensory analysis were submitted to statistical analysis considering the WCG inclusion levels as a fixed effect and panelists as a random effect. The Poisson distribution was analyzed using the PROC GLIMMIX procedure of SAS 9.4. The variables were evaluated adopting 0.05 as the critical level of probability for type-I error.

\section{Results}

\subsection{Intake and Carcass Characteristics}

Total dry matter intake decreased $(p<0.01)$, whereas EE intake $(p<0.01)$ increased as WCG was included in the diets (Table 2).

Table 2. Average nutrient intake during the experimental period, quantitative, subjective, and carcasses morphometric measurements of feedlot lambs fed diets with whole corn germ (WCG).

\begin{tabular}{|c|c|c|c|c|c|c|c|c|}
\hline \multirow[t]{2}{*}{ Item } & \multicolumn{5}{|c|}{$\begin{array}{l}\text { Inclusion Level of WCG } \\
\text { (g/kg DM) }\end{array}$} & \multirow[t]{2}{*}{ SEM } & \multicolumn{2}{|c|}{$p$-Value ${ }^{1}$} \\
\hline & 0 & 30 & 60 & 90 & 120 & & $\mathbf{L}$ & $\mathbf{Q}$ \\
\hline \multicolumn{9}{|c|}{ Total intake (kg) } \\
\hline Dry matter & 72.9 & 70.6 & 64.7 & 55.2 & 59.2 & 2.26 & $<0.01$ & 0.30 \\
\hline Crude protein & 13.8 & 13.7 & 13.6 & 13.7 & 13.7 & 0.06 & 0.15 & 0.20 \\
\hline Ether extract & 2.5 & 3.5 & 4.4 & 5.4 & 6.4 & 0.01 & $<0.01$ & 0.27 \\
\hline \multicolumn{9}{|c|}{ Weights (kg) } \\
\hline Initial weight & 26.9 & 28.0 & 26.5 & 25.8 & 25.8 & - & - & - \\
\hline Final weight & 42.7 & 43.5 & 42.1 & 41.8 & 41.5 & 0.71 & 0.07 & 0.64 \\
\hline Hot carcass weight & 18.2 & 17.9 & 18.0 & 18.0 & 18.1 & 0.63 & 0.99 & 0.68 \\
\hline Cold carcass weight & 17.7 & 17.4 & 17.5 & 17.5 & 17.6 & 0.62 & 0.97 & 0.77 \\
\hline \multicolumn{9}{|c|}{ Yields (\%) } \\
\hline Hot carcass yield & 42.5 & 41.5 & 43.0 & 42.9 & 42.0 & 1.13 & 0.98 & 0.75 \\
\hline Cold carcass yield & 41.3 & 40.3 & 42.0 & 41.8 & 40.7 & 1.10 & 0.96 & 0.63 \\
\hline \multicolumn{9}{|c|}{ Subjective evaluation } \\
\hline Conformation & 3.0 & 2.7 & 3.0 & 2.9 & 2.8 & 0.12 & 0.92 & 0.95 \\
\hline Finishing & 2.7 & 2.6 & 2.6 & 2.3 & 2.8 & 0.14 & 0.94 & 0.08 \\
\hline Marbling & 2.3 & 2.1 & 2.1 & 2.2 & 2.2 & 2.12 & 0.95 & 0.56 \\
\hline \multicolumn{9}{|c|}{ Morphometric measurements $(\mathrm{cm})$} \\
\hline External length & 54.5 & 55.0 & 53.5 & 55.1 & 53.8 & 1.02 & 0.74 & 0.91 \\
\hline Internal length & 56.2 & 57.6 & 55.2 & 55.8 & 54.2 & 1.47 & 0.24 & 0.61 \\
\hline Leg length & 36.5 & 35.8 & 35.5 & 36.6 & 34.4 & 0.83 & 0.22 & 0.61 \\
\hline Leg circumference & 44.6 & 44.1 & 44.8 & 44.1 & 41.2 & 0.81 & 0.01 & 0.04 \\
\hline Chest width & 25.4 & 24.6 & 24.6 & 24.0 & 24.7 & 0.68 & 0.36 & 0.41 \\
\hline Rump width & 20.4 & 20.2 & 20.4 & 20.0 & 20.2 & 0.63 & 0.77 & 0.94 \\
\hline Chest depth & 26.8 & 25.3 & 24.8 & 25.3 & 24.2 & 0.58 & 0.01 & 0.44 \\
\hline Rump perimeter & 52.5 & 52.0 & 53.8 & 53.2 & 54.5 & 1.08 & 0.18 & 0.79 \\
\hline \multicolumn{9}{|c|}{ Longissimus lumborum muscle } \\
\hline Loin eye area $\left(\mathrm{cm}^{2}\right)$ & 10.9 & 10.9 & 10.4 & 11.5 & 11.5 & 0.73 & 0.50 & 0.61 \\
\hline Subcutaneous fat thickness (mm) & 2.9 & 2.3 & 2.3 & 2.3 & 3.3 & 0.25 & 0.31 & $<0.01$ \\
\hline
\end{tabular}

${ }^{1} \mathrm{~L}=$ linear; $\mathrm{Q}=$ quadratic; significant at $p<0.05$. 
No effect was observed from the inclusion of WCG $(p>0.05)$ on the FW, subjective evaluation (conformation, finishing, and marbling), carcass yields, and LEA of the lambs (Table 2). However, the inclusion of WCG had a quadratic effect on SFT $(p<0.01)$, with a minimum value of $2.31 \mathrm{~mm}$ observed at the WCG level of $46.9 \mathrm{~g} / \mathrm{kg}$ DM.

The inclusion of WCG in the diet of lambs did not influence $(p>0.05)$ the morphometric measurements, with the exception of leg circumference $(p=0.01)$ and chest depth $(p=0.01)$, which decreased linearly (Table 2$)$.

\subsection{Physicochemical Composition and Sensory Attributes of the Meat}

The dietary inclusion of WCG had a quadratic effect on lightness ( $\left.L^{*} ; p=0.04\right)$, yellowness $\left(\mathrm{b}^{*} ; p<0.01\right)$, and WBSF $(p=0.04)$ (Table 3$)$ with the maximum values of $39.6,6.9$, and $3.2 \mathrm{kgf} / \mathrm{cm}^{2}$, estimated at WCG levels of $63.0,67.0 \mathrm{~g} / \mathrm{kg}$ and $55 \mathrm{~g} / \mathrm{kg}$ DM respectively.

Table 3. Physicochemical composition, and sensory attributes of the Longissimus lumborum muscle of feedlot lambs fed diets with whole corn germ (WCG).

\begin{tabular}{|c|c|c|c|c|c|c|c|c|}
\hline \multirow[t]{2}{*}{ Item } & \multicolumn{5}{|c|}{$\begin{array}{l}\text { Inclusion Level of WCG } \\
\text { (g/kg DM) }\end{array}$} & \multirow[t]{2}{*}{ SEM } & \multicolumn{2}{|c|}{$p$-Value ${ }^{1}$} \\
\hline & 0 & 30 & 60 & 90 & 120 & & $\mathbf{L}$ & $\mathbf{Q}$ \\
\hline $\mathrm{pHOh}$ & 6.8 & 7.0 & 6.6 & 6.7 & 7.0 & 0.10 & 0.67 & 0.11 \\
\hline $\mathrm{pH} 24 \mathrm{~h}$ & 6.4 & 6.0 & 5.8 & 6.1 & 6.0 & 0.18 & 0.27 & 0.13 \\
\hline \multicolumn{9}{|l|}{ Color parameter } \\
\hline Lightness $\left(\mathrm{L}^{*}\right)$ & 36.5 & 38.7 & 39.9 & 39.0 & 37.1 & 1.16 & 0.69 & 0.04 \\
\hline Redness $\left(a^{*}\right)$ & 19.4 & 20.6 & 20.0 & 20.5 & 20.2 & 0.38 & 0.27 & 0.19 \\
\hline Yellowness $(b *)$ & 5.0 & 6.3 & 7.7 & 6.8 & 6.0 & 0.45 & 0.10 & $<0.01$ \\
\hline Shear force $\left(\mathrm{kgf} / \mathrm{cm}^{2}\right)$ & 2.7 & 2.8 & 3.4 & 2.9 & 2.5 & 0.26 & 0.60 & 0.04 \\
\hline Cooking weight loss (\%) & 20.8 & 18.8 & 20.0 & 17.1 & 18.8 & 2.26 & 0.42 & 0.50 \\
\hline \multicolumn{9}{|c|}{ Chemical composition } \\
\hline Moisture & 73.8 & 73.6 & 73.5 & 73.2 & 73.7 & 0.38 & 0.64 & 0.40 \\
\hline Ash & 1.1 & 1.1 & 1.1 & 1.1 & 1.1 & 0.02 & 0.45 & 0.27 \\
\hline Crude protein & 22.0 & 21.2 & 22.0 & 22.2 & 21.1 & 0.34 & 0.56 & 0.29 \\
\hline Ether extract & 3.0 & 3.8 & 3.1 & 3.4 & 3.3 & 0.31 & 0.69 & 0.46 \\
\hline \multicolumn{9}{|c|}{ Sensory attributes } \\
\hline Flavor & 6.3 & 6.5 & 6.3 & 6.5 & 6.5 & 0.28 & 0.68 & 0.90 \\
\hline Tenderness & 7.7 & 7.5 & 7.1 & 7.6 & 7.7 & 0.28 & 0.96 & 0.41 \\
\hline Juiciness & 7.3 & 7.1 & 6.7 & 7.3 & 7.3 & 0.27 & 0.95 & 0.42 \\
\hline Aroma & 6.6 & 6.9 & 6.7 & 7.1 & 6.7 & 0.26 & 0.62 & 0.56 \\
\hline Overall acceptance & 6.9 & 7.0 & 6.7 & 7.0 & 7.0 & 0.27 & 0.73 & 0.72 \\
\hline
\end{tabular}

${ }^{1} \mathrm{~L}=$ linear; $\mathrm{Q}=$ quadratic; significant at $p<0.05$.

The inclusion of WCG did not influence $(p>0.05)$ the proximate composition and sensory attributes of the LL muscle of lambs (Table 3).

\subsection{Meat Fatty Acid Profile}

The concentrations of the fatty acids in the LL muscle of lambs did not change $(p>0.05)$ with WCG inclusion in the diet (Table 4). However, the inclusion of WCG had a quadratic effect in the concentration of linoleic fatty acid (C18:2 n-6) $(p=0.03)$, with a maximum value of $1408 \mathrm{mg} / \mathrm{kg}$, estimated at a WCG level of $76.7 \mathrm{~g} / \mathrm{kg}$. 
Table 4. Fatty acid composition (mg/kg of meat) of the Longissimus lumborum muscle of feedlot lambs fed diets with whole corn germ (WCG).

\begin{tabular}{|c|c|c|c|c|c|c|c|c|}
\hline \multirow[t]{2}{*}{ Item } & \multicolumn{5}{|c|}{$\begin{array}{l}\text { Inclusion Level of WCG } \\
\text { (g/kg DM) }\end{array}$} & \multirow[t]{2}{*}{ SEM } & \multicolumn{2}{|c|}{$p$-Value ${ }^{1}$} \\
\hline & 0 & 30 & 60 & 90 & 120 & & $\mathbf{L}$ & $\mathbf{Q}$ \\
\hline & \multicolumn{8}{|c|}{ Saturated fatty acids (SFA) } \\
\hline Caprylic (C8:0) & 11.7 & 15.0 & 17.5 & 15.0 & 17.4 & 2.31 & 0.16 & 0.46 \\
\hline Capric (C10:0) & 67.3 & 61.8 & 49.3 & 65.8 & 66.2 & 9.37 & 0.95 & 0.27 \\
\hline Lauric (C12:0) & 42.7 & 38.7 & 33.8 & 48.1 & 46.8 & 5.95 & 0.38 & 0.30 \\
\hline Myristic (C14:0) & 625 & 575 & 582 & 586 & 617 & 74.4 & 0.98 & 0.58 \\
\hline Pentadecanoic (C15:0) & 87.6 & 95.2 & 79.7 & 73.9 & 77.8 & 15.43 & 0.43 & 0.96 \\
\hline Palmitic (C16:0) & 7023 & 6459 & 6936 & 5917 & 6557 & 732 & 0.55 & 0.75 \\
\hline Heptadecanoic (C17:0) & 316 & 260 & 308 & 296 & 269 & 21.98 & 0.42 & 0.97 \\
\hline Stearic (C18:0) & 5098 & 4652 & 6153 & 4952 & 5039 & 375 & 0.88 & 0.27 \\
\hline Arachidic (20:0) & 36.8 & 33.1 & 44.0 & 36.1 & 37.3 & 2.61 & 0.63 & 0.39 \\
\hline \multirow[t]{2}{*}{ Behenic (22:0) } & 97.3 & 72.0 & 91.9 & 81.3 & 77.4 & 5.83 & 0.13 & 0.59 \\
\hline & \multicolumn{8}{|c|}{ Branched-chain fatty acids (BCFA) } \\
\hline Iso-14:0 & 8.5 & 6.1 & 10.8 & 8.4 & 8.2 & 1.20 & 0.66 & 0.58 \\
\hline iso- $-15: 0$ & 35.3 & 26.1 & 31.6 & 28.8 & 24.0 & 5.80 & 0.31 & 0.98 \\
\hline anteiso-15:0 & 37.6 & 28.5 & 42.4 & 36.6 & 30.1 & 4.71 & 0.66 & 0.43 \\
\hline iso- $-16: 0$ & 46.6 & 34.9 & 56.1 & 43.9 & 39.4 & 4.76 & 0.73 & 0.31 \\
\hline iso- $-17: 0$ & 7.2 & 6.3 & 5.0 & 5.4 & 4.5 & 1.07 & 0.09 & 0.66 \\
\hline anteiso-17:0 & 6.8 & 5.2 & 5.8 & 5.2 & 7.6 & 1.16 & 0.67 & 0.14 \\
\hline \multirow[t]{2}{*}{ iso- $-18: 0$} & 5.8 & 6.5 & 7.2 & 6.4 & 6.7 & 0.60 & 0.39 & 0.37 \\
\hline & \multicolumn{8}{|c|}{ Monounsaturated fatty acids (MUFA) } \\
\hline Miristoleic (C14:1) & 23.2 & 23.5 & 18.9 & 19.5 & 20.3 & 3.76 & 0.43 & 0.67 \\
\hline Palmitoleic (C16:1) & 605 & 544 & 531 & 366 & 495 & 83.21 & 0.17 & 0.48 \\
\hline C18:1 trans -9 & 5.4 & 6.6 & 9.3 & 6.2 & 8.4 & 3.12 & 0.60 & 0.78 \\
\hline C18:1 trans-10 & 213 & 201 & 252 & 216 & 222 & 19.46 & 0.62 & 0.50 \\
\hline Vaccenic (C18:1 trans-11) & 375 & 473 & 532 & 519 & 588 & 88.89 & 0.12 & 0.70 \\
\hline Cis-vaccenic (C18:1 cis-11) & 311 & 270 & 271 & 217 & 264 & 34.58 & 0.21 & 0.37 \\
\hline \multirow[t]{2}{*}{ Oleic $($ C18:1 n-9) } & 13,181 & 11,427 & 12,667 & 10,021 & 11,417 & 1477 & 0.32 & 0.67 \\
\hline & \multicolumn{8}{|c|}{ Polyunsaturated fatty acids (PUFA) } \\
\hline Linoleic (C18:2 n-6) & 1182 & 1175 & 1538 & 1344 & 1329 & 65.15 & 0.04 & 0.03 \\
\hline CLA $^{2}$ & 91.9 & 101 & 135 & 102 & 133 & 17.99 & 0.17 & 0.73 \\
\hline CLA (C18:2 trans-10 cis- 12$)$ & 10.7 & 10.5 & 11.4 & 12.1 & 10.5 & 1.10 & 0.74 & 0.47 \\
\hline$\alpha$-linolenic (C18:3 n-3) & 87.8 & 72.7 & 73.3 & 73.6 & 83.1 & 9.79 & 0.79 & 0.21 \\
\hline Arachidonic (C20:4 n-6) & 293 & 277 & 337 & 311 & 265 & 25.88 & 0.79 & 0.16 \\
\hline $\begin{array}{l}\text { Eicosapentaenoic (EPA; } \\
\text { C20:5 n-3) }\end{array}$ & 57.3 & 45.7 & 71.4 & 45.4 & 36.1 & 10.24 & 0.22 & 0.25 \\
\hline $\begin{array}{c}\text { Docosapentaenoic (DPA; } \\
\text { C22:5 n-3) }\end{array}$ & 81.3 & 69.7 & 77.1 & 74.7 & 61.9 & 9.43 & 0.29 & 0.74 \\
\hline $\begin{array}{c}\text { Docosahexaenoic (DHA; } \\
\text { C22:6n-3) }\end{array}$ & 19.1 & 16.1 & 20.1 & 18.4 & 14.0 & 2.47 & 0.34 & 0.38 \\
\hline
\end{tabular}

${ }^{1} \mathrm{~L}=$ linear; $\mathrm{Q}=$ quadratic; significant at $p<0.05$; CLA, conjugated linoleic acid (C18:2 cis-9 trans- $11 /$ trans-7 cis-9); ${ }^{2}$ coeluted peak with C18:2 trans-7 cis- 9 and C18:2 cis-9 trans-11.

The inclusion of WCG in the lambs' diet had a quadratic effect on the total polyunsaturated fatty acids (PUFAs) $(p=0.04$ ), with a maximum value observed of $2072 \mathrm{mg} / \mathrm{kg}$, estimated at WCG levels of $71.8 \mathrm{~g} / \mathrm{kg}$ DM and linear effect on the omega- 6 :omega-3 ratio $(p=0.03)$ (Table 5). However, no effect $(p>0.05)$ was observed from the inclusion of WCG on the other fatty acid sums, enzymatic activities of $\Delta 9$-desaturase and elongase, as well as the levels of nutritional quality of the lipid fraction related to human health. 
Table 5. Fatty acid groups, sums $(\Sigma)$, ratios, and nutritional quality of lipid fraction ( $\mathrm{mg} / \mathrm{kg}$ of meat) of the Longissimus lumborum muscle of feedlot lambs fed diets with whole corn germ (WCG).

\begin{tabular}{|c|c|c|c|c|c|c|c|c|}
\hline \multirow[t]{2}{*}{ Item $^{1}$} & \multicolumn{5}{|c|}{$\begin{array}{c}\text { Inclusion Level of WCG } \\
\text { (g/kg DM) }\end{array}$} & \multirow[t]{2}{*}{ SEM } & \multicolumn{2}{|c|}{$p$-Value ${ }^{2}$} \\
\hline & 0 & 30 & 60 & 90 & 120 & & L & $Q$ \\
\hline SFA & 13,552 & 12,352 & 14,454 & 12,204 & 12,926 & 1114 & 0.70 & 0.90 \\
\hline MUFA & 14,714 & 12,835 & 14,277 & 11,365 & 13,014 & 1592 & 0.36 & 0.66 \\
\hline PUFA & 1824 & 1768 & 2263 & 1982 & 1933 & 92.04 & 0.17 & 0.04 \\
\hline BCFA & 146 & 107 & 158 & 132 & 120 & 16.52 & 0.63 & 0.74 \\
\hline MUFA:SFA & 1.1 & 1.0 & 0.9 & 0.9 & 1.0 & 0.05 & 0.15 & 0.27 \\
\hline PUFA:SFA & 0.13 & 0.15 & 0.16 & 0.17 & 0.15 & 0.01 & 0.31 & 0.27 \\
\hline DFA & 21,637 & 19,256 & 22,694 & 18,300 & 19,987 & 1847 & 0.49 & 0.96 \\
\hline Neutral & 5165 & 4713 & 6202 & 5018 & 5106 & 375 & 0.88 & 0.28 \\
\hline Total & 32,576 & 29,229 & 33,464 & 27,733 & 30,206 & 2800 & 0.51 & 0.87 \\
\hline$\sum-6$ & 385 & 378 & 472 & 413 & 398 & 30.40 & 0.55 & 0.17 \\
\hline$\sum-3$ & 158 & 131 & 169 & 138 & 112 & 17.17 & 0.15 & 0.32 \\
\hline omega-6:omega-3 & 2.5 & 3.1 & 2.9 & 3.1 & 3.6 & 0.30 & 0.03 & 0.90 \\
\hline Atherogenicity index & 0.6 & 0.6 & 0.5 & 0.6 & 0.6 & 0.02 & 0.54 & 0.19 \\
\hline Thrombogenicity index & 1.6 & 1.7 & 1.7 & 1.8 & 1.7 & 0.07 & 0.15 & 0.40 \\
\hline Hypocholesterolemic (h) & 14,738 & 12,950 & 14,620 & 11,752 & 13,073 & 1454 & 0.35 & 0.76 \\
\hline Hypercholesterolemic $(\mathrm{H})$ & 8319 & 8238 & 8101 & 7009 & 7736 & 977 & 0.43 & 0.85 \\
\hline $\mathrm{h}: \mathrm{H}$ index & 1.9 & 1.8 & 1.9 & 1.8 & 1.8 & 0.05 & 0.26 & 0.63 \\
\hline$\Delta^{9}$-desaturase C16 & 7.8 & 7.1 & 7.0 & 7.1 & 7.0 & 0.37 & 0.14 & 0.42 \\
\hline$\Delta^{9}$-desaturase $\mathrm{C} 18$ & 71.3 & 70.0 & 66.8 & 67.0 & 68.6 & 2.07 & 0.24 & 0.26 \\
\hline Elongase & 70.6 & 70.1 & 71.6 & 70.7 & 70.0 & 0.74 & 0.77 & 0.28 \\
\hline
\end{tabular}

${ }^{1}$ SFA, saturated fatty acid; MUFA, monounsaturated fatty acid; PUFA, polyunsaturated fatty acid; DFA, desirable fatty acids; $\Sigma-6$, sum of omega-6 fatty acids; $\Sigma-3$, sum of omega-3 fatty acids; h:H, hypocholesterolemic to hypercholesterolemic FA ratio (h:H) index; ${ }^{2} \mathrm{~L}=$ linear; $\mathrm{Q}$ $=$ quadratic; significant at $p<0.05$.

\section{Discussion}

\subsection{Nutrient Intake and Carcass Characteristics}

The decrease of DM intake can be related to the chemostatic regulation of voluntary intake due to the increased EE intake and its content in the diets [40]. The WCG used in the current study had $41.2 \% \mathrm{EE}$ in its composition. Consequently, there was a range of $\mathrm{EE}$ content in the experimental diets from 3.1 to $7.6 \%$. Despite being a good energy source, EE levels above $5 \%$ in ruminant diets can be toxic to ruminal microorganisms [41].

The DM intake observed in the current study is in agreement with the results previously reported by Urbano et al. [3]. According to the authors, there was a decrease in lambs' nutrient intake when WCG totally replaced ground corn. The diet tested by them reached values of up to $12 \% \mathrm{EE}$.

According to De Souza et al. [42], higher ATP and metabolizable energy are obtained through long-chain fatty acids from the diet in comparison to short-chain fatty acids from ruminal digestion. The WCG inclusion in lambs' diets did not influence the FW and the quantitative characteristics of the carcasses. These results can be explained and related to the higher intake of lipids and, consequently, available metabolizable energy. In this way, there was an efficient use of the protein for muscle growth [43]. Therefore, the animals maintained similar performance levels, even with the reduction of dry matter intake.

Although the quadratic effect obtained for the SFT of the carcasses does not have a biological explanation, the higher energy input due to the dietary inclusion of WCG contributed to the increase of this parameter, which was $3.3 \mathrm{~mm}$ in the highest level of WCG tested.

The higher diets' energy density with the WCG inclusion contributed not only to the animals' energy requirements and may have promoted higher finishing of the carcasses [44]. This may have also favored, consequently, the preservation of meat quality, which was confirmed with the lowest WBSF values in the meat of these animals (Table 3). 


\subsection{Physicochemical Composition and Sensory Attributes of the Meat}

The mean $\mathrm{pH}$ values of meat were outside the recommended values reported by Sañudo et al. [45] for sheep meat, which is 6.56 to 6.69 for the initial $\mathrm{pH}$, and from 5.66 to 5.78 for the final $\mathrm{pH}$. Nevertheless, the lamb meat showed good quality and was not classified as dark, firm, and dry (DFD) or pale, soft, and exudative (PSE).

The $\mathrm{pH}$ varies according to the biochemical process of the transformation of muscle to meat. The glycogen, energetic muscle conductor, is converted into lactic acid, decreasing the $\mathrm{pH}$ of the meat. The animals in the current study were submitted to a period of preslaughter fasting ( $16 \mathrm{~h}$ of fasting for weighing and sending the animals to the slaughter).

When glycogen stores in muscle before slaughter decrease, it is likely to expect a higher ultimate $\mathrm{pH}$ and sometimes DFD meat. This characteristic is related to factors such as the animal age, inadequate nutrition, handling procedures before slaughter, transportation time to the slaughterhouse, long fasting period, and animal behavior, among others. Controlling these factors ensures necessary amounts of glycogen ( $57 \mu$ moles/g of muscle), essential for post-mortem muscle acidification [46].

Meat color can be influenced by several factors, including diet, intramuscular fat content, and $\mathrm{pH}$ values [47]. The high final $\mathrm{pH}$ (above 6.0) makes mitochondrial cytochrome oxidases more active. Thus, increased oxygen consumption may increase the concentration of deoxygenated myoglobin, resulting in dark-colored meats. In addition, the higher $\mathrm{pH}$ contributes to higher water retention capacity, making the meat paler [48]. In the current study, despite having a higher $\mathrm{pH}$ value after $24 \mathrm{~h}$, the results observed for color coordinates were not far from the values reported by Leão et al. [49] $\left(\mathrm{L}^{*}=45.68 ; \mathrm{a}^{*}=15.17\right.$; $\left.\mathrm{b}^{*}=4.93\right)$ in the sheep meat.

The results observed for color parameters of lightness $\left(\mathrm{L}^{*}\right)$ and the yellowness $\left(\mathrm{b}^{*}\right)$ can be related to the fat deposition in the meat. These findings are in agreement with the results reported by Fruet et al. [50]. They reported that higher values for lightness and yellowness in the meat of ewe fed diets exclusively with grains. Moreover, the carotenoid content deposited in the intramuscular fat of these animals' meat [51], from ground corn [52], can promote higher intensity of yellowness in fat. In turn, there is an increase in the luminosity of meat [53].

\subsection{Fatty Acid Profile}

In the current study, the most representative fatty acids in the LL muscle of lamb meat were oleic (C18:1 n-9), followed by the palmitic (C16:0), and stearic (C18:0) fatty acids. The same result was observed previously in other studies when the fatty acid profile was evaluated in lambs' meat [9,54-56]. The concentration of linoleic fatty acid (C18:2 n-6) in lambs' meat was an important finding in the current study. The inclusion of $76.7 \mathrm{~g} / \mathrm{kg}$ of WCG provided the highest value in the lambs' meat (1408 mg $/ \mathrm{kg}$ of meat). The increase in C18:2 n- 6 content in the meat of lambs fed with this dietary inclusion level of WCG may also be directly related to the content of this fatty acid in diets (Table 1).

The concentration of C18:2 n- 6 was high in the WCG used in the experimental diets, and a part of this fatty acid, in the materials' matrix, may have escaped from ruminal biohydrogenation [57]. This result is in agreement with the report of Urbano et al. [8], who mentioned higher levels of C18:2 n-6 and CLA (C18:29c 11t) fatty acids in the lambs' meat when animals were fed diets with total replacing of ground corn by WCG.

Both in humans and for animals, the C18:2n-6, as well as alpha-linolenic acid (C18:3n-3), precursors of the omega- 6 and omega- 3 long-chain fatty acid groups, are necessary to maintain cell membranes, brain functions, and transmission of nerve impulses under normal conditions [58]. Moreover, the C18:2n-6 fatty acid acts as precursor to conjugated linoleic acids (CLAs), known for their health benefits, especially the reduction of body fat, which makes it an influential role in the control of chronic non-communicable diseases [59].

Oils and vegetable by-products composed of high amounts of fat are used in ruminant diets to improve milk and meat fat quality [1]. This use is supported by the fact that 
these oilseeds' lipid profile has high rates of essential fatty acids, such as C18:1, C18:2 n-6, and C18:3 n-3 [60].

Saoussem et al. [61] evaluated the fatty acid profile of WCG and its main parts (germ, pericarp, and endosperm). They observed that the germ concentrates about $65.4 \%$ of C18:2 n-6 of the total fatty acids. In the current study, the higher C18:2 n-6 content contributed to the increase in total PUFA in the lambs' meat. Moreover, it is a fatty acid of the n-6 family and, consequently, increased these fatty acids sums. Nevertheless, the n-6:n3 ratio remained within the recommended value proposed by the Food and Agriculture Organization (FAO) [62] for human health (n-6:n-3 from 5:1 to 10:1).

\section{Conclusions}

Whole corn germ can be used up to $120 \mathrm{~g} / \mathrm{kg}$ DM in the total diet for feedlot lambs without causing negative impact. Carcass and meat quality changes based on the quantitative characteristics, physicochemical composition, and sensory attributes of the meat.

The inclusion of WCG in lambs' diets decreased dry matter intake. In this way, its inclusion increased the feeding efficiency and the possibility of better economic results because a smaller amount of feed was included in the diets during the feedlot period.

Nevertheless, if the meat industry seeks a better quality product, under the nutritional aspect, the level of $76.7 \mathrm{~g} / \mathrm{kg}$ DM of WCG provides higher concentrations of polyunsaturated fatty acids in the meat, especially the linoleic acid that contributes to the increase of fatty acids beneficial to human health.

Author Contributions: Conceptualization, G.G.P.d.C., D.S.P., and S.A.S.; methodology, C.O.N., T.C.G.C.R., W.P.S., and M.N.S.S.; software, D.S.P.; validation, G.G.P.d.C., D.S.P., and S.A.S.; formal analysis, C.O.N., T.C.G.C.R., W.P.S., and M.N.S.S.; investigation, C.O.N., T.C.G.C.R., W.P.S., and M.N.S.S.; resources, G.G.P.d.C., D.S.P., and S.A.S.; data curation, G.G.P.d.C. and D.S.P.; writing—original draft preparation, C.O.N., T.C.G.C.R., W.P.S., and M.N.S.S.; writing-review and editing, G.G.P.d.C., D.S.P., S.A.S., M.L.G.M.L.A., L.G.A.C., and H.D.R.A.; visualization, G.G.P.d.C., D.S.P., and S.A.S.; supervision, M.L.G.M.L.A., L.G.A.C., and H.D.R.A.; project Administration, G.G.P.d.C., D.S.P., and S.A.S.; funding acquisition, G.G.P.d.C., D.S.P., and S.A.S. All authors read and agreed to the published version of the manuscript.

Funding: This research was funded by the Bahia State Research Foundation (FAPESB—grant number: 8390/2014).

Institutional Review Board Statement: This study was conducted in strict accordance with the recommendations presented in the Guide of the National Council for Animal Experimentation Control (CONCEA). The protocol was approved by the Ethics Committee on the Animal Use of the School of Veterinary Medicine and Animal Science at the Federal University of Bahia (Permit number: 70/2018).

Informed Consent Statement: Not applicable.

Data Availability Statement: No new data were created or analyzed in this study. Data sharing is not applicable to this article.

Acknowledgments: The authors are thankful to the Bahia State Research Foundation (FAPESB) for the fellowship grant.

Conflicts of Interest: The authors declare no conflict of interest. The funders had no role in the design of the study; in the collection, analyses, or interpretation of data; in the writing of the manuscript, or in the decision to publish the results.

\section{References}

1. Miller, W.F.; Shirley, J.E.; Titgemeyer, E.C.; Brouk, M.J. Comparison of full-fat corn germ, whole cottonseed, and tallow as fat sources for lactating dairy cattle. J. Dairy Sci. 2009, 92, 3386-3391. [CrossRef]

2. Miotto, F.R.C.; Neiva, J.N.M.; Restle, J.; Falcão, A.J.D.S.; Castro, K.J.D.; Maciel, R.P. Ingestive behavior of bulls fed diets containing levels of whole corn germ. Ciênc. Anim. Bras. 2014, 15, 45-54. [CrossRef] 
3. Urbano, S.A.; de Andrade Ferreira, M.; Bispo, S.V.; da Silva, E.C.; Suassuna, J.M.A.; de Oliveira, J.P.F. Corn germ meal in replacement of corn in Santa Ines sheep diet: Carcass characteristics and tissue composition. Acta Vet. Bras. 2016, 10, 165-171. [CrossRef]

4. Lima, M.B.D.; Rabello, C.B.V.; Silva, E.P.D.; Lima, R.B.; Arruda, E.M.F.D.; Albino, L.F.T. Effect of broiler chicken age on ileal digestibility of corn germ meal. Acta Scient. Ani. Sci. 2012, 34, 137-141. [CrossRef]

5. Abdelqader, M.M.; Hippen, A.R.; Kalscheur, K.F.; Schingoethe, D.J.; Karges, K.; Gibson, M.L. Evaluation of corn germ from ethanol production as an alternative fat source in dairy cow diets. J. Dairy Sci. 2009, 92, 1023-1037. [CrossRef] [PubMed]

6. Brito, A.B.D.; Stringhini, J.H.; Cruz, C.P.D.; Xavier, S.A.G.; Leandro, N.S.M.; Café, M.B. Effect of whole corn germ on broiler carcass performance and yield. Arq. Bras. Med. Vet. Zootec. 2005, 57, 241-249. [CrossRef]

7. Silva, E.C.D.; Ferreira, M.D.A.; Véras, A.S.C.; Bispo, S.V.; Conceição, M.G.D.; Siqueira, M.C.B.D.; Souza, A.R.D.L. Replacement of corn meal by corn germ meal in lamb diets. Pesq. Agropec. Bras. 2013, 48, 442-449. [CrossRef]

8. Urbano, S.A.; Ferreira, M.D.A.; Madruga, M.S.; Azevedo, P.S.D.; Bispo, S.V.; Silva, E.C.D. Corn germ as a substitute for corn in the diet of confined Santa Inês sheep: Chemical and lipid composition of meat. Ciênc. Agrotec. 2014, 38, 581-588. [CrossRef]

9. Guerreiro, O.; Alves, S.P.; Soldado, D.; Cachucho, L.; Almeida, J.M.; Francisco, A.; Jerónimo, E. Inclusion of the aerial part and condensed tannin extract from Cistus ladanifer L. in lamb diets-Effects on growth performance, carcass and meat quality and fatty acid composition of intramuscular and subcutaneous fat. Meat Sci. 2020, 160, 107945. [CrossRef]

10. Dugan, M.E.R.; Cletos, M.; Payam, V. Polyunsaturated fatty acid biosynthesis and metabolism in agriculturally important species. In Polyunsaturated Fatty Acid Metabolism; Burdge, G., Ed.; Academic Press: Southampton, UK; AOCS Press: Southampton, UK, 2018; pp. 61-86. [CrossRef]

11. Dijkstra, A.J. Vegetable Oils: Types and Properties. In Encyclopedia of Food and Health; Caballero, B., Finglas, P.M., Toldrá, F., Eds.; Elsevier: Oxford, UK; Academic Press: Waltham, MA, USA, 2016; pp. 517-522. [CrossRef]

12. NRC-National Research Council. Nutrient Rrequirements of Small Ruminants; National Academic Press: Washington, DC, USA, 2007.

13. AOAC. Official Methods of Analysis of the Association of Official Analytical Chemists, 18th ed.; Association of Official Analytical Chemists Inc.: Gaithersburg, MD, USA, 2005.

14. Mertens, D.R. Gravimetric determination of amylase-treated neutral detergent fiber in feeds with refluxing in beakers or crucibles: Collaborative study. J. AOAC Int. 2002, 85, 1217-1240.

15. Van Soest, P.V.; Robertson, J.B.; Lewis, B.A. Methods for dietary fiber, neutral detergent fiber, and nonstarch polysaccharides in relation to animal nutrition. J. Dairy Sci. 1991, 74, 3583-3597. [CrossRef]

16. AOAC. Official Methods of Analysis of the Association of Official Analytical Chemists, 17th ed.; Association of Official Analytical Chemists Inc.: Washington, DC, USA, 2002.

17. Licitra, G.; Hernandez, T.M.; Van Soest, P.J. Standardization of procedures for nitrogen fractionation of ruminant feeds. Anim. Feed Sci. Technol. 1996, 57, 347-358. [CrossRef]

18. Hall, M.B. Calculation of Non-Structural Carbohydrate Content of Feeds That Contain Non-Protein Nitrogen; University of Florida: Gainesville, FL, USA, 2000.

19. FAO—Food and Agriculture Organization. Guidelines for Humane Handling, Transport and Slaughter of Livestock: Slaughter of Livestock; Food and Agriculture Organization of United Nation: Bangkok, Thailand, 2001.

20. Cézar, M.F.; Sousa, W.H. Sheep and Goat Carcasses: Production, Evaluation and Classification; Agropecuária Tropical: Uberaba, Brazil, 2007.

21. Osório, J.C.S.; Osório, M.T.; Jardim, P.O. Methods for the Evaluation of Sheep Meat Production: 'In Vivo', in the Carcass and in the Meat; University Graphic Publisher-UFPEL: Pelotas, Brazil, 1998.

22. Colomer-Rocher, F.; Morand-Fehr, P.; Kirton, A.H. Standard methods and procedures for goat carcass evaluation, jointing and tissue separation. Livest. Prod. Sci. 1987, 17, 149-159. [CrossRef]

23. Silva Sobrinho, A.G. Body Composition and Characteristics of Carcass from Lambs of Different Genotypes and Ages at Slaughter. Ph.D. Thesis, Massey University, Palmerston North, New Zealand, 1999.

24. Cañeque, V.; Sañudo, C. Methodology for the Study of the Quality of the Carcass and Meat in Ruminants; Instituto Nacional de Investigación y Tecnologia y Alimenticia: Madrid, Spain, 2000.

25. Miltenburg, G.A.; Wensing, T.; Smulders, F.J.; Breukink, H.J. Relationship between blood hemoglobin, plasma and tissue iron, muscle heme pigment, and carcass color of veal. J. Anim. Sci. 1992, 70, 2766-2772. [CrossRef] [PubMed]

26. Duckett, S.K.; Klein, T.A.; Dodson, M.V.; Snowder, G.D. Tenderness of normal and callipyge lamb aged fresh or after freezing. Meat Sci. 1998, 49, 19-26. [CrossRef]

27. Wheeler, T.L.; Koohmaraie, M.; Shackelford, S.D. Standardized Warner Bratzler Shear Force Procedures for Meat Tenderness Measurement; Agricultural Research Service: Clay Center, NE, USA, 1995. [CrossRef]

28. AMSA-American Meat Science Association. Research Guidelines for Cookery, Sensory Evaluation, and Instrumental Tenderness Measurements of Meat, 2nd ed.; American Meat Science Association: Champaign, IL, USA, 2015.

29. O'Fallon, J.V.; Busboom, J.R.; Nelson, M.L.; Gaskins, C.T. A direct method for fatty acid methyl ester (FAME) synthesis: Application to wet 5 meat tissues, oils and feedstuffs. J. Anim. Sci. 2007, 85, 1511-1521. [CrossRef] 
30. Kramer, J.K.; Fellner, V.; Dugan, M.E.; Sauer, F.D.; Mossoba, M.M.; Yurawecz, M.P. Evaluating acid and base catalysts in the methylation of milk and rumen fatty acids with special emphasis on conjugated dienes and total trans fatty acids. Lipids 1997, 32, 1219-1228. [CrossRef]

31. Kramer, J.K.; Blackadar, C.B.; Zhou, J. Evaluation of two GC columns (60-m SUPELCOWAX 10 and 100-m CP sil 88) for analysis of milkfat with emphasis on CLA, 18:1, 18:2 and 18:3 isomers, and short-and long-chain FA. Lipids 2002, 37, 823-835. [CrossRef]

32. Bravo-Lamas, L.; Barron, L.J.; Kramer, J.K.; Etaio, I.; Aldai, N. Characterization of the fatty acid composition of lamb commercially available in northern Spain: Emphasis on the trans-18:1 and CLA content and profile. Meat Sci. 2016, 117, 108-116. [CrossRef]

33. Sukhija, P.S.; Palmquist, D.L. Rapid method for determination of total fatty acid content and composition of feedstuffs and feces. J. Agric. Food Chem. 1988, 36, 1202-1206. [CrossRef]

34. Rhee, K.S. Fatty acids in meats and meat products. In Fatty Acids in Foods and Their Health Implications; Chow, C.K., Ed.; Marcel Dekker: New York, NY, USA, 1992; pp. 65-93.

35. Malau-Aduli, A.E.O.; Siebert, B.D.; Bottema, C.D.K.; Pitchford, W.S. A comparison of the fatty acid composition of tryacilglycerols in adipose tissue from Limousin and Jersey cattle. Aust. J. Agric. Res. 1997, 48, 715-722. [CrossRef]

36. Kazala, E.C.; Lozeman, F.J.; Mir, P.S.; Laroche, A.; Bailey, D.R.; Weselake, R.J. Relationship of fatty acid composition to intramuscular fat content in beef from crossbred Wagyu cattle. J. Anim. Sci. 1999, 77, 1717-1725. [CrossRef] [PubMed]

37. Ulbricht, T.L.V.; Southgate, D.A.T. Coronary heart disease: Seven dietary factors. Lancet 1991, 338, 985-992. [CrossRef]

38. Bessa, R.J.B. Nutritional revaluation of ruminant fats. In Symposium Europeo-Alimentación en el Siglo XXI; Calcro, R., GómezNieves, J.M., Eds.; Official College of Veterinarians of Badajoz: Badajoz, Spain, 1999; pp. 283-313.

39. Santos-Silva, J.; Bessa, R.J.B.; Santos-Silva, F. Effect of genotype, feeding system and slaughter weight on the quality of light lambs: Fatty and composition of meat. Livest. Prod. Sci. 2002, 77, 187-194. [CrossRef]

40. Haddad, S.G.; Younis, H.M. The effect of adding ruminally protected fat in fattening diets on nutrient intake, digestibility and growth performance of Awassi lambs. Anim. Feed Sci. Technol. 2004, 113, 61-69. [CrossRef]

41. Palmquist, D.L.; Mattos, W.R.S. Lipid metabolism. In Ruminant Nutrition; Berchielli, T.T., Pires, A.V., Oliveira, S.G., Eds.; Funep: Jaboticabal, Brazil, 2006; pp. 287-310.

42. De Souza, J.; Batistel, F.; Santos, F.A.P. Effect of sources of calcium salts of fatty acids on production, nutrient digestibility, energy balance, and carryover effects of early lactation grazing dairy cows. J. Dairy Sci. 2017, 100, 1072-1085. [CrossRef]

43. Fernandes, A.R.M.; Orrico, M.A.P., Jr.; Orrico, A.C.A.; Vargas, F.M.D., Jr.; Oliveira, A.B.D.M. Performance and qualitative characteristics of carcasses and meat of lambs finished in confinement and fed diets containing soybean grain or protected fat. Rev. Bras. Zootec. 2011, 40, 1822-1829. [CrossRef]

44. Brand, T.S.; Van Der Merwe, D.A.; Swart, E.; Hoffman, L.C. The effect of finishing period and dietary energy content on the carcass characteristics of Boer goats. Small Rumin. Res. 2019, 174, 110-117. [CrossRef]

45. Sañudo, C.; Sierra, I.; Olleta, J.L.; Martin, L.; Campo, M.M.; Santolaria, P.; Wood, J.D.; Nute, G.R. Influence of weaning on carcass quality, fatty acid composition and meat quality in intensive lamb production systems. Anim. Sci. 1998, 66, 175-187. [CrossRef]

46. Ponnampalam, E.N.; Hopkins, D.L.; Bruce, H.; Li, D.; Baldi, G.; Bekhit, A.E.D. Causes and contributing factors to "dark cutting" meat: Current trends and future directions: A review. Compr. Rev. Food Sci. Food Saf. 2017, 16, 400-430. [CrossRef]

47. Sañudo, C.; Muela, E.; Campo, M.M. Key factors involved in lamb quality from farm to fork in Europe. J. Integ. Agric. 2013, 12, 1919-1930. [CrossRef]

48. Bressan, M.C.; Prado, O.V.; Pérez, J.R.O.; Lemos, A.; Bonagurio, S. Effect of slaughter weight of Santa Inês and Bergamácia lambs on the physical and chemical characteristics of meat. Food Sci. Technol. 2001, 21, 293-303. [CrossRef]

49. Leão, A.G.; Silva Sobrinho, A.G.D.; Moreno, G.M.B.; Souza, H.B.A.D.; Giampietro, A.; Rossi, R.C.; Perez, H.L. Physico-chemical and sensory characteristics of lamb meat finished with diets containing sugar cane or corn silage and two levels of concentrate. Braz. J. Anim. Sci. 2012, 1253-1262. [CrossRef]

50. Fruet, A.P.B.; Stefanello, F.S.; Júnior, A.G.R.; de Souza, A.N.M.; Tonetto, C.J.; Nörnberg, J.L. Whole grains in the finishing of culled ewes in pasture or feedlot: Performance, carcass characteristics and meat quality. Meat Sci. 2016, 113, 97-103. [CrossRef] [PubMed]

51. Kirton, A.H.; Crane, B.; Paterson, D.J.; Clare, N.T. Yellow fat in lambs caused by carotenoid pigmentation. N. Z. J. Agric. Res. 1975, 18, 267-272. [CrossRef]

52. Egesel, C.O.; Wong, J.C.; Lambert, R.J.; Rocheford, T.R. Combining ability of maize inbreds for carotenoids and tocopherols. Crop Sci. 2003, 43, 818-823. [CrossRef]

53. Krzywicki, K. Assessment of relative content of myoglobin. oxymyoglobin and metmyoglobin at the surface of beef. Meat Sci. 1979, 3, 1-10. [CrossRef]

54. Bezerra, L.S.; Barbosa, A.M.; Carvalho, G.G.P.; Simionato, J.I.; Freitas, J.E., Jr.; Araújo, M.L.G.M.L.; Pereira, L.; Silva, R.R.; Lacerda, E.C.Q.; Carvalho, B.M.A. Meat quality of lambs fed diets with peanut cake. Meat Sci. 2016, 121, 88-95. [CrossRef]

55. Majewska, M.P.; Pajak, J.J.; Skomiał, J.; Kowalik, B. The effect of different forms of sunflower products in diets for lambs and storage time on meat quality. Anim. Feed Sci. Technol. 2016, 222, 227-235. [CrossRef]

56. Facciolongo, A.M.; Lestingi, A.; Colonna, M.A.; Nicastro, F.; De Marzo, D.; Toteda, F. Effect of diet lipid source (linseed vs. soybean) and gender on performance, meat quality and intramuscular fatty acid composition in fattening lambs. Small Rumin. Res. 2018, 159, 11-17. [CrossRef] 
57. Nguyen, D.V.; Malau-Aduli, B.S.; Cavalieri, J.; Nichols, P.D.; Malau-Aduli, A.E.O. Supplementation with plant-derived oils rich in omega-3 polyunsaturated fatty acids for lamb production. Vet. Anim. Sci. 2018. [CrossRef] [PubMed]

58. Montecillo-Aguado, M.; Tirado-Rodrigues, B.; Tong, Z.; Vega, O.M.; Morales-Martínez, M.; Abkenari, S.; Pedraza-Chaverri, J.; Huerta-Yepez, S. Importance of the Role of $\omega-3$ and $\omega-6$ Polyunsaturated Fatty Acids in the Progression of Brain Cancer. Brain Sci. 2020, 10, 381. [CrossRef] [PubMed]

59. Chang, H.; Gan, W.; Liao, X.; Wei, J.; Lu, M.; Chen, H.; Liu, X. Conjugated linoleic acid supplements preserve muscle in high-body-fat adults: A double-blind, randomized, placebo trial. Nutr. Metab. Cardiov. Dis. 2020. [CrossRef] [PubMed]

60. Peng, Y.S.; Brown, M.A.; Wu, J.P.; Liu, Z. Different oilseed supplements alter fatty acid composition of different adipose tissues of adult ewes. Meat Sci. 2010, 85, 542-549. [CrossRef]

61. Saoussem, H.; Sadok, B.; Habib, K.; Mayer, P.M. Fatty acid accumulation in the different fractions of the developing corn kernel. Food Chem. 2009, 117, 432-437. [CrossRef]

62. FAO-Food and Agriculture Organization. WHO and FAO Joint Consultation: Fats and oils in human nutrition. Nutr. Rev. 1995, 53, 202-205. 